\title{
In Vitro Evaluation of Antibacterial Chemicals and Bioagents against Ralstonia solanacearum Infecting Bacterial Wilt in Ginger
}

\author{
Roop Singh* and G.P. Jagtap \\ Department of Plant Pathology, Vasantrao Naik Marathwada Krishi Vidyapeeth, \\ Parbhani - 431402, Maharashtra, India \\ *Corresponding author
}

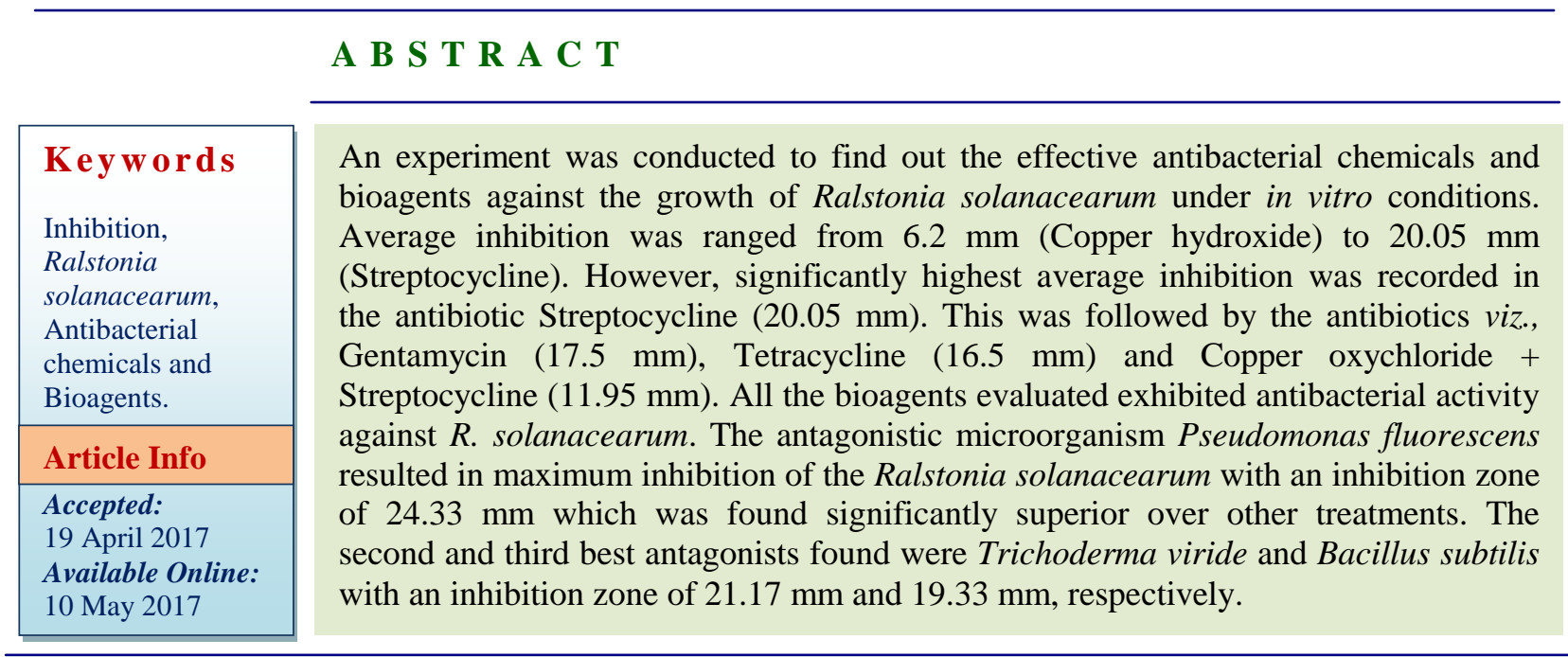

\section{Introduction}

Bacterial wilt caused by $R$. solanacearum is deemed to be one of the most important plant diseases in tropical agriculture (Hayward, 1990; Milling et al., 2011). It has a large host range of more than 200 species in 50 families (Aliye et al., 2008). Bacterial wilt disease is one of the major constraints of ginger in small and marginal farming communities. The strain causing bacterial wilt of ginger in India belongs either to biovar 3 or 4 ; the former being the most virulent in India (Kumar and Sarma, 2004; Kumar and Hayward, 2005). Sambasivam and Girija (2005) reported host resistant and loss in ginger cultivation by $R$. solanacearum in Kerala. Many a times this important cash crop is subjected to premature wilting resulting in $100 \%$ crop loss. $R$. solanacearum is a gram negative, rod shaped, strictly aerobic bacterium that is $0.5-0.7 \times 1.5-$ $2.0 \mu \mathrm{m}$ in size, with a single polar flagellum. Individual bacterial colonies are usually visible after 36 to $48 \mathrm{hrs}$ of growth at $28^{\circ} \mathrm{C}$ and colonies of ginger strains were highly fluidal with characteristic spiral pink centre whereas in the case of other strains fluidity and pink centre was less conspicuous (Kumar and Sarma, 2004; Sambasivam and Girija, 2006). Occasionally colonies of the mutant or non virulent type appear uniformly round, smaller and butyrous or dry. A Kelman's selective nutrient tetrazolium chloride (TZC) medium (Kelman, 1954) can differentiate the 
two colony types on this medium. Strains of $R$. solanacearum have been classified into five biovars (Kumar et al., 1993) and five races (Buddenhagen et al., 1962; Bin Li et al., 2010). The characteristic symptoms of bacterial wilt of ginger include green leaves roll and curl due to water stress caused by bacteria blocking the water-conducting vascular system of the ginger stems, leaf yellowing and necrosis (Nelson, 2013; White et al., 2013).

The aim of present investigation was to study the effect of antibacterial chemical and bioagents on growth of $R$. solanacearum under in vitro conditions.

\section{Materials and Methods}

\section{Isolation of $R$. solanacearum from bacterial wilt affected ginger plant and soil}

The diseased plant and soil samples were collected from the farmer's field. The diseased plant samples were washed under tap water to remove the soil particle and air dried. The pseudostem of diseased plant of length 10 to $15 \mathrm{~cm}$ was first surface-disinfected with 70 $\%$ ethanol for 2 minutes and $1 \%$ sodium hypochloride for 5 minutes followed by repeated washing in sterile water for 5 minutes to remove traces of sodium hypochloride. The surface sterilized bits were suspended in the five-milliliter sterile distilled water taken in test tube for ten minutes. After the water in test tube becomes turbid due to oozing of bacterial cells from cut ends of diseased tissue, the bacterial suspension was serially diluted in nine $\mathrm{ml}$ sterile water. One hundred microliter $(1 \mathrm{ml})$ of the bacterial suspension was poured onto the surface of solidified Triphenyl tetrazolium chloride agar (TZC) medium (Kelmen, 1954) containing $(\mathrm{g} / \mathrm{L})$ peptone $10 ;$ casein hydrolysate 1; glucose 5; agar 20; and distilled water 1L; pH 7.0 (1 \% TZC will added to a final concentration of $5 \mathrm{ml} / \mathrm{L}$ after autoclaving) using spread plate technique. A loopful of bacterial suspension was streaked into TZC medium and incubated at $28 \pm 2^{\circ} \mathrm{C}$ for 48 hours.

To isolate the pathogen from soil, the soil samples were serially diluted and pathogen was isolated using TZC medium. At the end of incubation period, the plates were observed for the development of both the virulent and avirulent colonies of $R$. solanacearum. The virulent colonies were irregularly shaped, fluidal, dull white colonies with pink center, whereas, avirulent colonies small, round, convex, butyrous with large red pigment and white fluidal colonies without pink center described by Kelman (1954).

\section{Pathogenicity test}

Pathogenecity test was attempted to established host-pathogen interaction by pseudostem inoculation method (Kumar, 2006). The ginger sprouts were raised by planting $30 \mathrm{~g}$ bits of seed rhizomes in steam sterilized standard potting mixture with soil, sand, and FYM in 3:1:1 ratio. Forty five days old plants were used for inoculation and a control treatment without inoculation was maintained.

The pathogenicity was conducted by preparing aqueous suspension of the bacterium grown on $\mathrm{CPG}$ or NA broth medium with a concentration of $5 \times 10^{8} \mathrm{cfu} / \mathrm{ml}$. Twenty micro liters of suspension was poured at the base of ginger plants by making injury to the pseudostem of ginger plants in pots. The pots were maintained at 25 per cent moisture holding capacity. The nutrients required for the plant growth were supplied through nutrient solution at an interval of fifteen days. The plants were watered 
regularly and observations on appearance of wilt symptoms were recorded. The plants expressing wilt symptoms were selected and bacterium was re-isolated as explained under above isolated pathogen showing typical characteristic of $R$. solanacearum so as to satisfy the Koch's postulate.

\section{In vitro evaluation of antibacterial chemicals}

Six antibiotics (each @ 400 and 500ppm), three fungicides (each @ 1500 and 2000 ppm) and two combinations of fungicide + antibiotic [(1000:500) and (1500:500)] by inhibiton zone assay method were evaluated in vitro against $R$. solanacearum. The mass multiplied broth culture of the test bacterium $\left(2 \times 10^{8} \mathrm{cfu} / \mathrm{ml}\right)$ was seeded to autoclaved Nutrient agar medium, mixed thoroughly and poured into sterilized glass Petri plates allowed to solidify.

The solutions of the desired concentrations of the test antibiotics and fungicides were prepared separately. The filter paper discs (Whatman No. 42) of $5 \mathrm{~mm}$ in diameter were soaked separately in the respective chemical solutions for $5-10 \mathrm{~m}$ minutes and transformed in center onto the solidified bacterium seeded NA medium in Petri plates. The inoculated plates were kept in the refrigerator at $4^{0} \mathrm{C}$ for 4 hours to allow diffusion of the chemical into medium. The untreated control plate containing with the test bacterium seeded NA and inoculated with filter paper disc soaked in distilled water was also maintained then the plates were incubated at $28^{0} \mathrm{C}$ for 48 hours and observed for the production of inhibition zone around filter paper discs.

\section{In vitro evaluation bioagents/antagonists}

\section{Bacterial antagonists}

Two isolates of bacterial antagonist's viz., Pseudomonas fluorescence and Bacillus subtilis collected from Department of Plant Pathology were tested for their efficacy in inhibiting the growth $R$. solanacearum by paper disc method. The virulent isolates $R$. solanacerum was multiplied on Nutrient broth. The 48 hours old culture of $R$. solanacerum containing $2 \times 10^{8} \mathrm{cfu} / \mathrm{ml}$ was mixed with molten $\left(50^{\circ} \mathrm{C}\right)$ Nutrient agar, so as to get a thick lawn of bacteria on the surface of agar medium. The seeded medium poured into sterilized Petri-plates and allowed to solidify. Previously sterilized filter paper (Whatman No. 42) measuring $5 \mathrm{~mm}$ in diameter were soaked in different antagonist broth for 10 minutes and placed in the Petriplates. The excess solution from the filter paper disc was removed by touching slide of the paper discs to the lid of Petri dishes containing broth of the same organism. Then the filter disc was placed in a marked position on the surface of the seeded agar medium. The inoculated plates were incubated at $28 \pm 2^{\circ} \mathrm{C}$ for 48 hours. The observations for the production of inhibition zone around the filter paper discs were recorded at 24, 48 and 72 hours of incubation respectively. The obtained results were analyzed statistically. Filter paper discs dipped in sterile water served as check.

\section{Fungal antagonists}

Six fungal isolates collected from the Department of plant pathology were tested for their inhibitory effect on $R$. solanacearum in vitro by inhibition zone assay method. All the fungal isolates were grown separately on Potato Dextrose Agar. The virulent isolate of $R$. solanacearum was multiplied on Nutrient broth. The 48 hours old culture of $R$. solanacearum containing $2 \times 10^{8} \mathrm{cfu} / \mathrm{ml}$ was mixed with molten $\left(50^{\circ} \mathrm{C}\right)$ sterilized PDA $(20$ $\mathrm{ml}$ ), then seeded PDA poured in sterilized Petri-plates and allowed solidify. Fungal discs of 5 diameters from margin of actively growing four days old culture removed and 
placed in the center of the plates containing PDA. The plates were incubated at $28 \pm 2^{\circ} \mathrm{C}$ for 4 days. The observation on the zone of inhibition around the mycelial disc against Ralstonia solanacearum was recorded after the incubation period.

\section{Results and Discussion}

\section{Isolation of the pathogen}

Isolation was made from the soil samples and bacterial ooze (Fig.1) obtained from the infected discolored pseudostem of the plants by serially diluting the bacterial suspension in sterile distilled water and planting on TZC media (Kelman, 1954). Typical virulent colonies of $R$. solanacearum developed within 48 hours. The virulent colonies appeared well-separated, irregular fluidal, dull white colored with slight pink centre (Fig.2) and non-virulent colonies appeared dark red on TZC media (Fig.3). The Colonies were irregular fluidal, creamy white color on Casamino acid peptone glucose agar (CPG) media. The well separated colonies were picked up and purified further by single colony isolation technique and then suspended in sterile distilled water in sterile plastic ependorf tubes and stored at room temperature this served as stock culture for further use. Similar results were also reported (Lemessa and Zeller, 2007A; Chakravarty and Kalita, 2011; Chaudhry and Rashid, 2011; Sagar et al., 2014).

\section{Pathogenicity test}

The bacterium was inoculated to the host plant (Ginger) under artificial condition by pseudostem inoculation method in screen house. The inoculated plant showed wilting symptoms 15 days after the inoculation. The isolate was found to be pathogenic to host plant, expressing wilt symptoms. The inoculated plant lost turgidity; leaves started dropping and plant wilted suddenly (Fig.4).
Pathogenicity of $R$. solanacearum causing bacterial wilt was proved earlier by several workers (Winstead and Kelman, 1952; Schell M. A., 2000; Williamson et al., 2002; Rajan et al., 2002; Kumar and Sarma, 2004; Umesha et al., 2005; Hikichi, 2007; Rashmi et al., 2012; Artal, 2012; Thomas and Upreti, 2014; Zulperi et al., 2014). Kumar A. (2006) proved the pathogenicity of $R$. solanacearum using susceptible ginger cultivar 'Himachal'. Mathews et al., (2008) also proved the pathogenicity of $R$. solanacearum using ornamental ginger species, the final pathogenicity assessment was recorded 21 DAI.

\section{In vitro evaluation of antibacterial chemicals against $R$. solanacearum}

Present investigation was carried out to evaluate antibacterial chemicals to find out their effectiveness against the growth of $R$. solanacearum under in vitro condition and the results were presented in Table 1 and Fig. 5.

Total six antibiotics viz., Sreptocycline, Cephalexin, Neomycin, Tetracycline, Dicrystacin, Gentamycin, and three antibacterial fungicides viz., Blitox (Copper oxy chloride) Kocide (Copper hydroxide) and Amistar individually and in combination Blitox + Streptocycline, Blitox + Tetracycline were evaluated in vitro by inhibition zone assay method against $R$. solanacearum.

\section{Antibiotics}

At 400 ppm, inhibition was ranged from 6.9 $\mathrm{mm}$ (Dicrystacin) to $18.4 \mathrm{~mm}$ (Streptocycline). However, significantly highest inhibition was recorded in the antibiotic Streptocycline $(18.4 \mathrm{~mm})$. This was followed by the antibiotics viz., Gentamycin $(15.4 \mathrm{~mm})$, Tetracycline $(14.2 \mathrm{~mm})$ and Neomycin $(8.1 \mathrm{~mm})$. Antibiotics, Cephalexin 
and Dicrystacin were found less effective with 7.5 and $6.9 \mathrm{~mm}$ inhibition, respectively.

At 500 ppm, inhibition was ranged from 7.0 $\mathrm{mm}$ (Dicrystacin) to $21.7 \mathrm{~mm}$ (Streptocycline). However, significantly highest inhibition was recorded in the antibiotic Streptocycline $(21.7 \mathrm{~mm})$. This was followed by the antibiotics viz., Gentamycin $(19.6 \mathrm{~mm})$, Tetracycline $(18.8 \mathrm{~mm})$ and Neomycin $(8.3 \mathrm{~mm})$. Antibiotics, Cephalexin and Dicrystacin were found less effective with 7.6 and $7.0 \mathrm{~mm}$ inhibition, respectively.

Average inhibition was ranged from $6.95 \mathrm{~mm}$ (Dicrystacin) to $20.05 \mathrm{~mm}$ (Streptocycline). However, significantly highest average inhibition was recorded in the antibiotic Streptocycline $(20.05 \mathrm{~mm})$. This was followed by the antibiotics viz., Gentamycin $(17.5 \mathrm{~mm})$, Tetracycline $(16.5 \mathrm{~mm})$ and Neomycin $(8.2 \mathrm{~mm})$. Antibiotics, Cephalexin and Dicrystacin were found less effective with 7.55 and $6.95 \mathrm{~mm}$ inhibition, respectively.

\section{Antibacterial fungicides}

At 1500 ppm, inhibition was ranged from 6.1 $\mathrm{mm}$ (Copper hydroxide) to $11.9 \mathrm{~mm}$ (Copper oxychloride + Streptocycline). However, significantly highest inhibition was recorded in the combination of antibacterial fungicide and antibiotic Copper oxychloride + Streptocycline $(11.9 \mathrm{~mm})$. This was followed by the antibacterial fungicides viz., Copper oxychloride (10.6 mm), Copper oxychloride + Tetracycline $(10.5 \mathrm{~mm})$. Antibacterial fungicides, Amistar and Copper hydroxide were found less effective with 7.2 and $6.1 \mathrm{~mm}$ inhibition, respectively. At 2000 ppm, inhibition was ranged from $6.3 \mathrm{~mm}$ (Copper hydroxide) to $12.0 \mathrm{~mm}$ (Copper oxychloride + Streptocycline). However, significantly highest inhibition was recorded in the combination of antibacterial fungicide and antibiotic Copper oxychloride + Streptocycline $(12.0 \mathrm{~mm})$. This was followed by the antibacterial fungicides viz., Copper oxychloride (11.6 mm), Copper oxychloride + Tetracycline $(10.7 \mathrm{~mm})$. Antibacterial fungicides, Amistar and Copper hydroxide were found less effective with 7.3 and $6.3 \mathrm{~mm}$ inhibition, respectively.

Average inhibition was ranged from $6.2 \mathrm{~mm}$ (Copper hydroxide) to $11.95 \mathrm{~mm}$ (Copper oxychloride + Streptocycline). However, significantly highest average inhibition was recorded in the combination of antibacterial fungicide and antibiotic Copper oxychloride + Streptocycline $(11.95 \mathrm{~mm})$. This was followed by the antibacterial fungicides viz., Copper oxychloride (11.1 mm), Copper oxychloride + Tetracycline $(10.6 \mathrm{~mm})$. Antibacterial fungicides, Amistar and Copper hydroxide were found less effective with 7.25 and $6.2 \mathrm{~mm}$ inhibition, respectively.

Thus, all the antibiotics/antibacterial chemicals tested were found effective against $R$. solanacearum. However, antibacterial chemicals found most effective in the order of merit were Streptocycline, Gentamycin, Tetracycline, Copper oxychloride + Streptocycline, Copper oxychloride, Copper oxychloride + Tetracycline, Neomycin, Cephalexin, Amistar and Dicrystacin.

These results are in conformity with the findings of those reported earlier by several workers (Hidaka and Murano, 1956; Dutta and Verma, 1969; Indersenan et al., 1981; Khan et al., 1997; Singh et al., 2000; Devnath et al., 2002; Dubey, 2005; Sunder et al., 2011; Gupta and Razdan, 2013; Owoseni and Sangoyomi, 2014).

\section{In vitro evaluation of bioagents/antagonists against $R$. solanacearum}

The six fungal antagonistic microorganism's viz., Trichoderma harzianum, Trichoderma 
viride, Trichoderma koningii, Gliocladium virens, Trichoderma longibrachiatum, Aspergillus niger and two bacterial antagonistic microorganisms viz., Pseudomonas fluorescens and Bacillus subtilis were evaluated against $R$. solanacearum under in vitro condition by inhibition zone method as explained in the material and methods.

Table.1 In vitro evaluation of antibacterial chemicals against $R$. solanacearum

\begin{tabular}{|c|l|c|c|c|}
\hline \multirow{2}{*}{ Tr. No. } & \multirow{2}{*}{ Antibiotics } & \multicolumn{3}{|c|}{ Inhibition zone (mm)* Concentration at } \\
\cline { 3 - 5 } & & $\mathbf{4 0 0} \mathbf{~ p p m}$ & $\mathbf{5 0 0} \mathbf{~ p p m}$ & Av. (mm) \\
\hline $\mathrm{T}_{1}$ & Sreptocycline & 18.4 & 21.7 & 20.05 \\
\hline $\mathrm{T}_{2}$ & Cephalexin & 7.5 & 7.6 & 7.55 \\
\hline $\mathrm{T}_{3}$ & Neomycin & 8.1 & 8.3 & 8.2 \\
\hline $\mathrm{T}_{4}$ & Tetracycline & 14.2 & 18.8 & 16.5 \\
\hline $\mathrm{T}_{5}$ & Dicrystacin & 6.9 & 7.0 & 6.95 \\
\hline $\mathrm{T}_{6}$ & Gentamycin & 15.4 & 19.6 & 17.5 \\
\hline & & \multicolumn{2}{|c|}{ Inhibition zone (mm)* Concentration at } \\
\cline { 3 - 5 } & Antibacterial fungicides & $\mathbf{1 5 0 0}$ ppm & $\mathbf{2 0 0 0} \mathbf{~ p p m}$ & Av. $(\mathbf{m m})$ \\
\hline $\mathrm{T}_{7}$ & Blitox (Copper oxy chloride) & 10.6 & 11.6 & 11.1 \\
\hline $\mathrm{T}_{8}$ & Kocide (Copper hydroxide) & 6.1 & 6.3 & 6.2 \\
\hline $\mathrm{T}_{9}$ & Amistar (Azoxystrobin) & 7.2 & 7.3 & 7.25 \\
\hline $\mathrm{T}_{10}$ & Blitox + Streptocycline & 11.9 & 12.0 & 11.95 \\
\hline $\mathrm{T}_{11}$ & Blitox + Tetracycline & 10.5 & 10.7 & 10.6 \\
\hline $\mathrm{T}_{12}$ & Control (Untreated) & 0.0 & 0.0 & 0.00 \\
\hline S.E. \pm & & $\mathbf{0 . 2 7}$ & $\mathbf{0 . 3 1}$ & - \\
\hline CD $(\mathbf{P} \mathbf{0 . 0 1})$ & & $\mathbf{0 . 8 0}$ & $\mathbf{0 . 9 2}$ & - \\
\hline & & \multicolumn{3}{|c}{} \\
\hline
\end{tabular}

*-Mean of three replications

Table.2 In vitro evaluation of biocontrol agents against $R$. solanacearum

\begin{tabular}{|c|l|c|}
\hline Tr. No. & \multicolumn{1}{|c|}{ Treatments } & Inhibition zone (mm) $*$ \\
\hline $\mathrm{T}_{1}$ & Trichoderma viride & 21.17 \\
\hline $\mathrm{T}_{2}$ & T. harzianum & 16.33 \\
\hline $\mathrm{T}_{3}$ & Gliocladium virens & 9.67 \\
\hline $\mathrm{T}_{4}$ & T. koningii & 8.33 \\
\hline $\mathrm{T}_{5}$ & T. longibrachiatum & 7.67 \\
\hline $\mathrm{T}_{6}$ & Pseudomonas fluorescence & 24.33 \\
\hline $\mathrm{T}_{7}$ & Bacillus subtilis & 19.33 \\
\hline $\mathrm{T}_{8}$ & Aspergillus niger & 10.33 \\
\hline $\mathrm{T}_{9}$ & Control (untreated) & 0.00 \\
\hline S.E. \pm & & $\mathbf{0 . 5 8}$ \\
\hline CD $(\mathbf{P ~ 0 . 0 1 )}$ & & $\mathbf{1 . 7 3}$ \\
\hline
\end{tabular}

*-Mean of three replications 
Fig.1\&2 Bacterial ooze from pseudostem of wilted ginger plant and Virulent colonies of $R$. solanacearum on TZC media
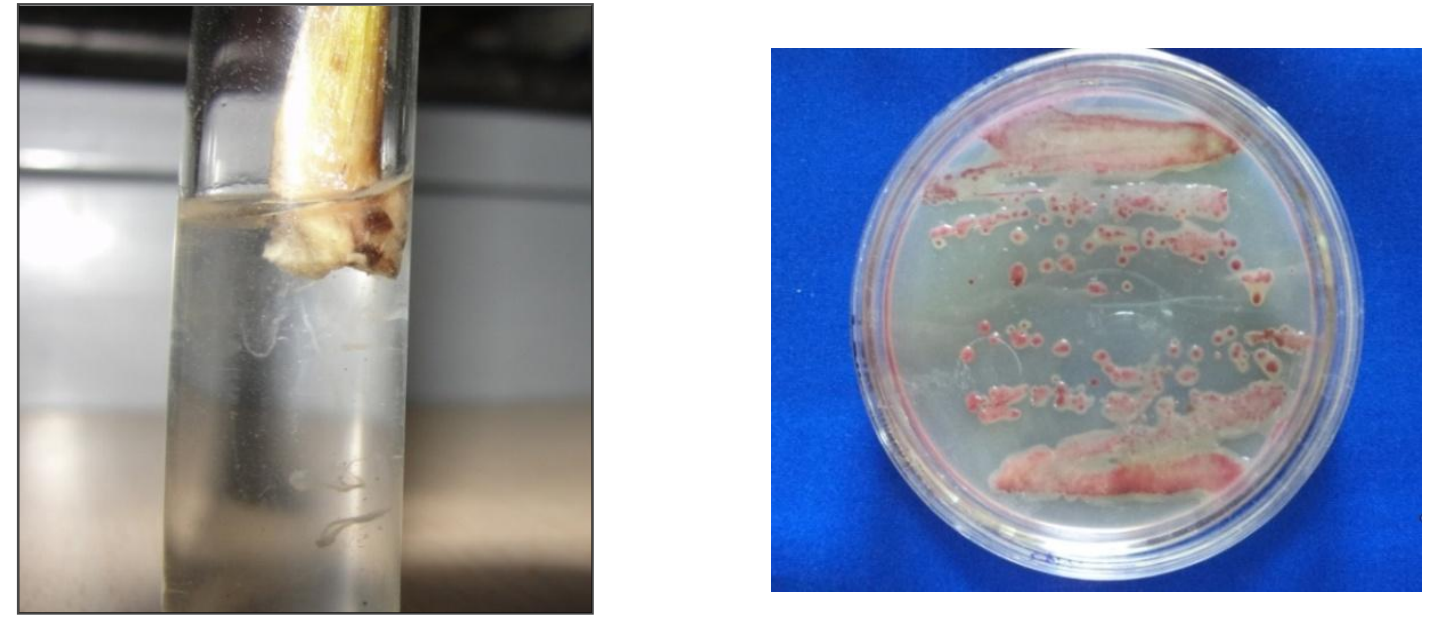

Fig.3 \& 4 A virulent colonies of $R$. solanacearum on TZC media and Pathogenicity test of $R$. solanacearum on ginger
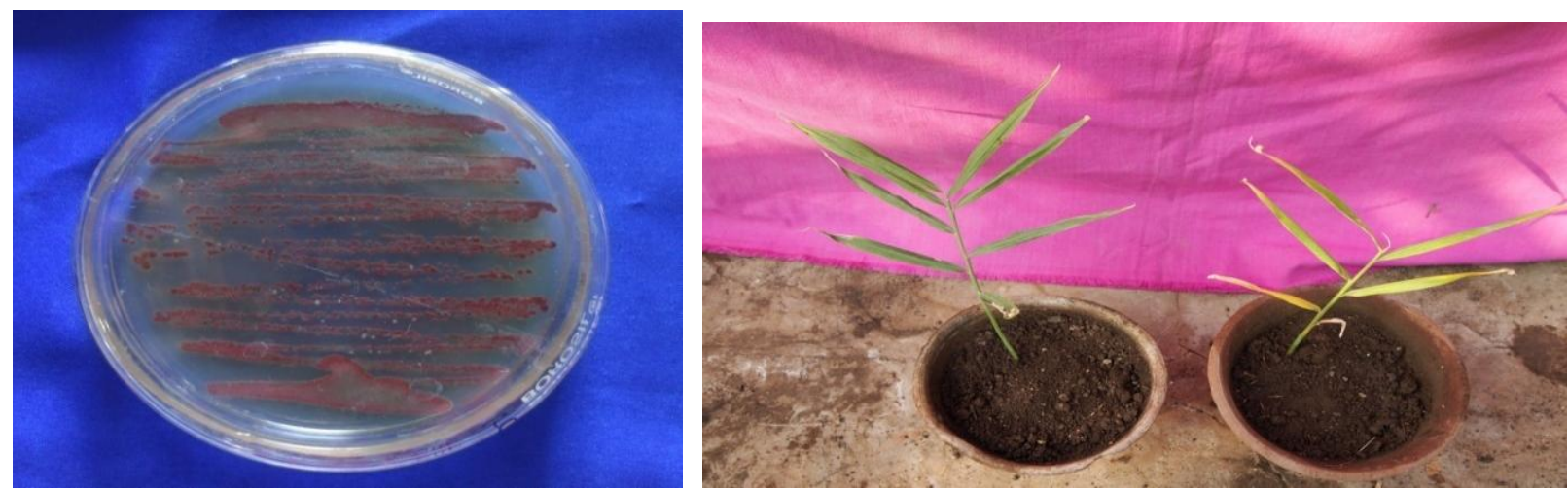

Fig.5 In vitro evaluation of antibacterial chemicals against $R$. solanacearum

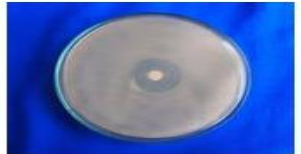

T.

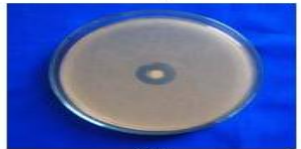

Ta
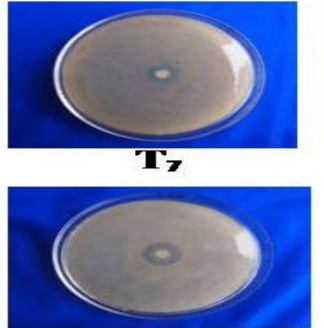

T10

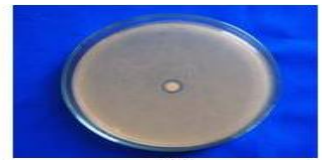

$\boldsymbol{T}_{\mathbf{2}}$

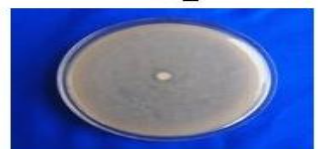

$T_{5}$

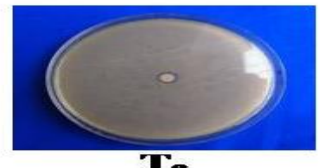

$\mathbf{1} \mathbf{8}$

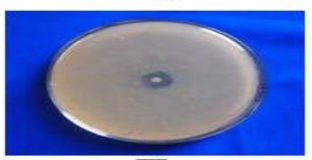

$\mathbf{T}_{\mathbf{1 1}}$
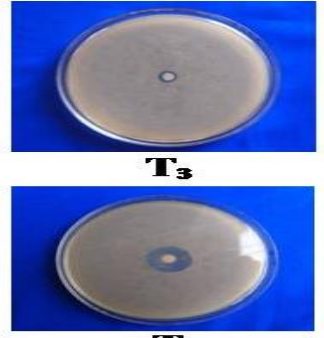

$T_{6}$
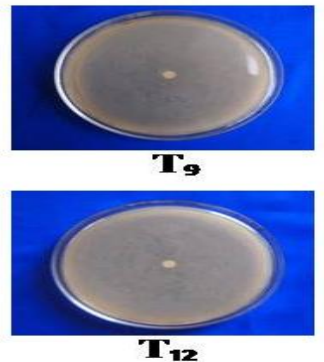
Fig.6 In vitro evaluation of bioagents against $R$. solanacearum

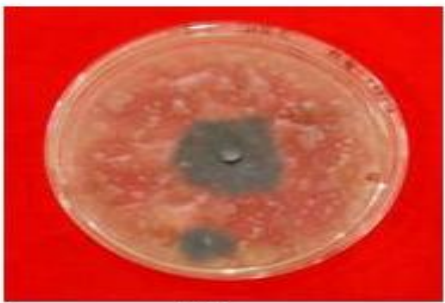

$\mathbf{T}_{1}$

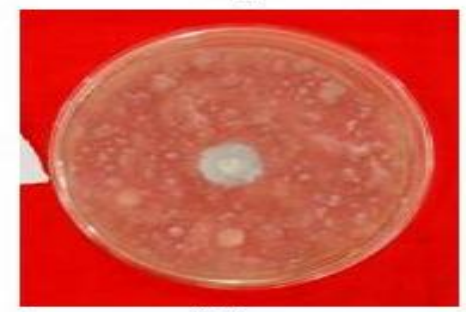

$\mathbf{T}_{4}$

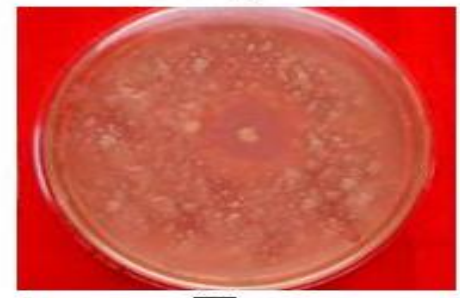

$\mathbf{T}_{\mathbf{7}}$

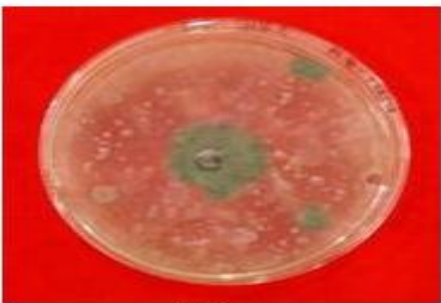

$\mathbf{T}_{\mathbf{2}}$

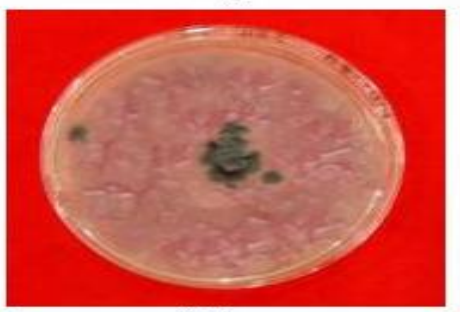

$\mathbf{T}_{\mathbf{5}}$

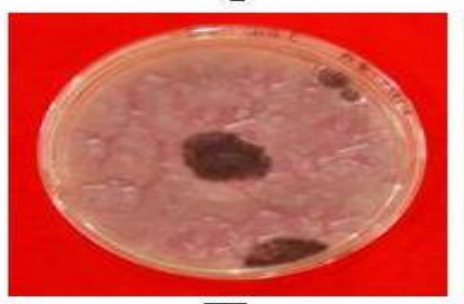

$\mathbf{T}_{\mathbf{8}}$

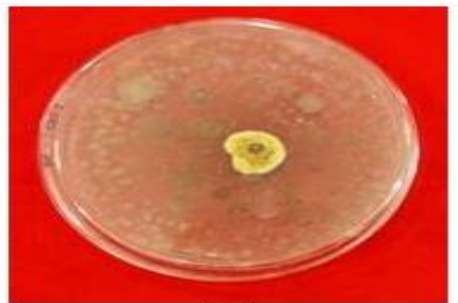

$\mathbf{T}_{\mathbf{3}}$

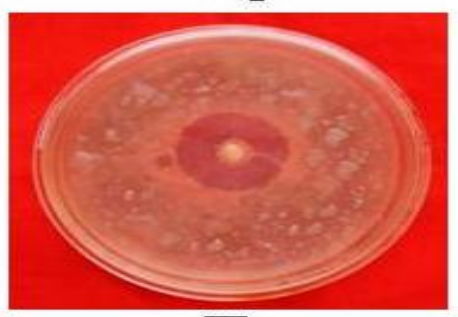

$\mathbf{T}_{6}$

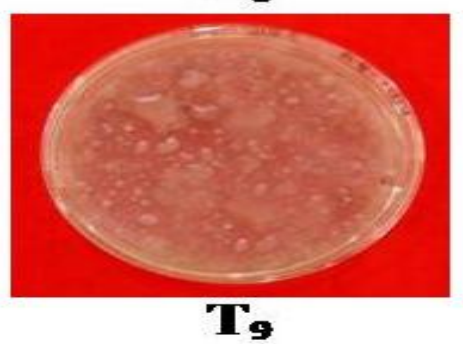

The results obtained on inhibition zone produced across the antagonistic microorganisms are presented in Table 2 and Fig.6. Results revealed that all the bioagents evaluated exhibited antibacterial activity against $R$. solanacearum. The results indicated that the antagonistic microorganism $P$. fluorescens resulted in maximum inhibition of the Ralstonia solanacearum with an inhibition zone of $24.33 \mathrm{~mm}$ which was found significantly superior over other treatments. The second and third best antagonists found were T. viride and Bacillus subtilis with an inhibition zone of $21.17 \mathrm{~mm}$ and $19.33 \mathrm{~mm}$, respectively. This was followed by $T$. harzianum $(16.33 \mathrm{~mm})$ and A. niger (10.33). Whereas, the antagonists like, G. virens, T. koningii and $T$. longibrachiatum were moderately effective with slight inhibition zone of $9.67 \mathrm{~mm}, 8.33 \mathrm{~mm}$ and $7.67 \mathrm{~mm}$, respectively. Bioagents viz., P. fluorescens and B. subtilis were reported efficient antagonists against $R$. solanacearum earlier by many workers (Guo et al., 2001; El-Sayed et al., 2003; Sun et al., 2004; Lemessa and Zeller, 2007 B; Henok et al., 2007; Liza and Bora, 2008; Vanita et al., 2009; Liza and Bora, 2009; Maketon et al., 2010; Choudhry and Rashid, 2011; Khair et al., 2012; Yang et al., 2012; Gupta and Razdan, 2013; Raghu et al., 2013). The species of Trichoderma viz., viride and harzianum were reported as efficient antagonists against $R$. solanacearum (Ramesh, 2006; Liza and Bora, 2009; Chaudhry and Rashid, 2011, Narsimbha and Srinivas, 2012; Gupta and Razdan, 2013; Raghu et al., 2013).

\section{References}

Aliye, N., Fininsa, C. and Hiskias, Y. 2008. Evaluation of rhizosphere bacterial 
antagonists for their potential to bioprotect potato (Solanum tuberosum) against bacterial wilt (Ralstonia solanacearum. Biol. Control, 47: 282288.

Artal, R.B., Gopalakrishnan C., Thippeswamy B. 2012. An efficient inoculation method to screen tomato, brinjal and chilli entries for bacterial wilt resistance. Pest Management in Horticultural Ecosystems., 18 (1): 7073.

Bin $\mathrm{Li}$, Ting $\mathrm{Su}$, Rongrong $\mathrm{Yu}$, Zhongyun Tao, Zhiyi Wu, Soad Algam A. E., Guanlin Xie, Yanli Wang and Guochang Sun. 2010. Inhibitory activity of Paenibacillus macerans and Paenibacillus polymyxa against Ralstonia Solanacearum. African J. Microbiol. Res., 4(19): 2048-2054.

Buddenhagen, I., Sequeria, L. and Kelman, A. 1962. Designation of races of Pseudomonas solanacearum. Phytopathol., 52: 72.

Chakravarty, G. and Kalita, M.C. 2011. Comparative evaluation of organic formulations of Psuedomonas fluorescens based pesticides and their application in the management of bacterial wilt of brinjal (Solanum melongena L). Afr. J. Biotechnol., 10: 7174-7182.

Chaudhry, Z. and Rasid Hamid. 2011. Isolation and characterization of Ralstonia solanacearum from infected tomato plants of soan skesar vally of Punjab. Pak. J. Bot., 43(6): 2979-2985.

Devanath, H.K., Pathank, J.J. and Bora, L.C. 2002. In vitro sensitivity of Ralstonia solanacearum causing bacterial wilt of ginger towards antagonists, plant extracts and chemicals. Nadia, India. J. of Interacademicia., 6(2): 250-253.

Dubey S. C. 2005. Integrated management of bacterial wilt of tomato. Pl. Dis. Res., 20 (1): 52-54.
Dutta, A.K. and Verma, S.S.P. 1969. Control of bacterial wilt of egg plant with streptocycline. Hindustan Antibiotics Bull., 11: 260-261.

Elphinstone, J.G. 2005. The current bacterial wilt situation: A global overview. bacterial wilt disease and the $R$. solanacearum complex. edited by Caitilyn Allen, Philippe Prior, and Hayward A.C. American Phytopathological society. St. Paul, Minnesota. P9.

EL-Sayed, W.M.A., Bayoumi, R.A. and GLGhafar, N.Y.A. 2003. Biological control of potato bacterial wilt disease under Egyptian condition. Ann. Agri. Sci., 48: 353-364.

Guo, J.H., Guo, Y.H., Zhang, L.X., Qi, H. Y. and Fang, Z.D. 2001. Screening for biocontrol agents against cayenne pepper bacterial wilt. China J. Biol. Control., 17: 101-106.

Gupta, V. and Razdan, V.K. 2013. Evaluation of antagonists and antibiotics against bacterial wilt of brinjal caused by Ralstonia solanacearum. Bioinfolet, 10(3A): 851-852.

Hayward, A.C., El-Nashaar. H.M., Nydegger, U. and Lindo, D.L. 1990. Variation in nitrate metabolism in biovars of Pseudomonas solanacearum. J. Appl. Bacteriol., 69: 269-280.

Henok, K., Fasil, A. and Yaynu, H. 2007. Evaluation of Ethiopian isolates of Pseudomonas fluorescens as biocontrol agent against potato bacterial wilt caused by Ralstonia (Pseudomonas) solanacearum. Acta agriculturae Slovenica, 90(2): 125-135.

Hidaka, Z. and Murano, H. 1956. Studies on the streptomycin for plants - I. Behaviour of $P$. solanacearum and $P$. tabaci treated with streptomycin in vitro and surface absorption of streptomycin in the plant. Ann. Phytopathol. Soc., Japan, 20: 143-147. 
Hikichi, Y., Yoshimochi, T. and Tsujimoto, S. 2007. Global regulation of pathogenicity mechanism of Ralstonia solanacearum. Plant Biotechnol., 24: $149-154$

Indersenan, G., Sreekumar, V., Mathew, J. and Mammen, M.K. 1981. The mode of survival of $P$. solanacearum causing bacterial wilt of ginger. Agril. Res. J. Kerala., 19: 93-95.

Kelman, A. 1954. The relationship of pathogenicity in Pseudomonas solanacearum to colony appearance on a tetrazolium medium. Phytopathol., 44: 693-695.

Khair, H. Abd-El, Nasr, H.I. and Seif El. 2012. Application of Bacillus subtilis and Trichoderma spp. for controlling the potato brown rot in field. Archives of Phytopathol. Plant Protection, 45(1): $1-15$.

Khan, A.N.A., Karuna, K., Ravikumar, M.R. and Kulkarni, R.S. 1997. Chemical control of bacterial wilt of tomato caused by Pseudomonas solanacearum (Abstract. $3^{\text {rd }}$ Int. Bact. Wilt. Symp.), pp 23-27.

Kishun, R. 1985. Effect of bacterial wilt on yield of tomato. Indian Phytopathol., 38: 606 .

Kumar A. 2006. Methods for screening ginger (Zingiber officinale Rosc.) for bacterial wilt resistance. Indian Phytopath., 59(3): 281-286.

Kumar, A. and Hayward, A.C. 2005. Bacterial diseases of ginger and their control. In: Ravindran PN, Babu KN (eds) Monograph on ginger, CRC Press, Boca Raton. pp 341-366.

Kumar, A. and Sarma, Y.R. 2004. Characterization of Ralstonia solanacearum causing bacterial wilt of ginger in India. Indian Phytopath., 57: 12-17.

Kumar, V., Singh, B.M. and Sugha, S.K. 1993. Variation in isolates of
Pseudomonas solanacearum from Himachal Pradesh. Indian J. Mycol. Plant Pathol., 23: 232-236.

Lemessa, F. and Zeller, W. 2007 B. Screening rhizobacteria for biological control of Ralstonia solanacearum in Ethiopia. Biol. Control, 42: 336-344.

Lemessa, F. and Zeller, W. 2007A. Isolation and characterization of Ralstonia solanacearum strains from solanaceous crops in Ethiopia. J. Bas. Microbiol., 47 (1): 40-49.

Liza Barua and Bora, B.C. 2008. Comparative efficacy of Trichoderma harzianum and Pseudomonas fluorescens against Meloidogyne incognita and Ralstonia solanacearum complex in Brinjal. Indian J. Nematol., 38(1): 86-89.

Liza Barua and Bora, B.C. 2009. Compatibility of Trichoderma harzianum and Pseudomonas fluorescens against Meloidogyne incognita and Ralstonia solanacearum complex on brinjal. Indian J. Nematol., 39(1): 29-34.

Lukyanenko, A.N. 1991. Disease resistance in tomato in genetic improvement of tomato (ed. Kallo, G.); Monographs on theoretical and applied genetics 14 . Springer Verlag, Berlin Heidelberg. pp. 99-119.

Maketon, M., Dararat, H. and Sirinatta S. 2010. Control of Bacterial wilt disease caused by Ralstonia solanacearum in Ginger and Postharvest Treatment by Antagonistic Microorganisms. American-Eurasian J. Agric. \& Environ. Sci., 7 (6): 728-739.

Mathews, L., Paret, A. S., Silva, D., Richard, A., and Alvarez, A. M. 2008. Ralstonia solanacearum Race 4: Risk assessment for edible ginger and floricultural ginger industries in Hawaii. Hort. Technol., 18(1): 55-58.

Milling, A., Babujee, L. and Allen, C. 2011. Ralstonia solanacearum Extracellular 
Polysaccharide Is a Specific Elicitor of Defense Responses in Wilt Resistant Tomato Plants. PLoS ONE, 6(1): e15853.

Narasimha Murthy K. and Srinivas, C. 2012. In vitro screening of bio antagonistic agents and plant extract to control bacterial wilt of tomato. J. Agri. Technol., 8(3): 999-1015.

Nelson Scot. 2013. Bacterial wilt of edible ginger in Hawaii. Plant Dis., PD-99.

Owoseni, A.A. and Sangoyomi, T.E. 2014. Effect of solvent extracts of some plants on Ralstonia solanacearum. British Microbiol. Res. J., 4(1): 89-96.

Raghu, S., Ravikumar, M.R., Santosh Reddy M., Basamma, B.K. and Benagi, V. I. 2013. In vitro evaluation of antagonist micro-organisms against Ralstonia solanacearum. Ann. Pl. Protec. Sci., 21(1): 176-223.

Rajan, P.P., Gupta, S.R., Sarma, Y.R. and Jackson G.V.H. 2002. Diseases of ginger and their control with Trichoderma harzianum. Indian Phytopath., 55(2): 173-177.

Ramesh, R. 2006. Field evaluation of biological control agents for the management of Ralstonia solanacearum in brinjal. J. Mycol. Pl. Pathol., 36(2): 327-328.

Rashmi, B., Artal, C., Krishnan, G. and Thippeswamy, B. 2012. An efficient inoculation method to screen tomato, brinjal and chilli entries for bacterial wilt resistance. Pest Management in Horticultural Ecosystems, 18(1): 70-73.

Sagar, V., Gurjar, M.S., Arjunan, J., Bakade, R.R., Chakrabarti, S.K., Arora, R.K. and Sharma, S. 2014. Phylotype analysis of Ralstonia solanacearum strains causing potato bacterial wilt in Karnataka in India. African $J$. Microbiol. Res., 8(12): 1277-1281.

Sambasivam, P.K. and Girija, D. 2005. Studies on host range and intrinsic antibiotic resistance pattern of Ralstonia solanacearum infecting ginger. Ann. Pl. Protec. Sci., 13: 431-433.

Sambasivam, P.K. and Girija, D. 2006. Biochemical characterization of Ralstonia solanacearum infecting Ginger. Ann. Pl. Protec. Sci., 14(2): 419-423.

Schell, M.A. 2000. Control of virulence and pathogenicity genes of Ralstonia solanacearum by an elaborate sensory network. Annu Rev Phytopathol., 38: 263-292.

Singh, D.K., Sinha, S.K., Singh, V.N. and Singh, D.N. 2000. Control of bacterial wilt of ginger (Zingiber officinale) with antibiotics. J. Res., 12: 41-43.

Sun, S., Wei, A. M., Wu, H. X. and Wang J. 2004. Advances in research on chemical and biological control of plant bacterial wilt. Jiangxi Plant Prot., 27(4): 157162.

Sunder, J., Jeyakumar, S., Kundu, A., Srivastava, R.C. and Kumar, D.A. 2011. Effect of Morinda citrifolia extracts on in-vitro growth of Ralstonia solanacearum. Arch. Appl. Sci. Res., 3 (3): 394-402.

Thomas, P. and Upreti, R. 2014. Influence of Seedling Age on the Susceptibility of Tomato Plants to Ralstonia solanacearum during Protray Screening and at Transplanting. American Journal of Plant Sci., 5: 1755-1762.

Umesha, S., Kavitha, R. and Shetty, H.S. 2005. Transmission of seed-borne infection of chilli by Burkholderia solanacearum and effect of biological seed treatment on disease incidence. Archives of Phytopathol. Plant Protection, 38 (4): 281-293.

Vanitha, S.C., Niranjana, S. R., Mortensen, C. N. and Umesham, S. 2009. Bacterial wilt of tomato in Karnataka and its management by Pseudomonas fluorescens. BioControl., 54: 685-695. 
White, F., Motomura, S., Miyasaka, S. and Kratky, B.A. 2013. A simplified method of multiplying bacterial wilt free edible ginger (Zingiber officinale) in Pots. Plant Dis., PD-93.

Williamson, L., Nakaho, K., Hudelson, B., and Allen, C. 2002. Ralstonia solanacearum race 3 , biovar 2 strains isolated from geranium are pathogenic on potato, Plant Dis., 86: 987-991.

Winstead, N.N., and Kelman, A. 1952. Inoculation techniques for evaluating resistance to Pseudomonas solanacearum. Phytopathol., 42: 628634.

Yang, W. 2012. Evaluation of biological control agents against Ralstonia wilt on ginger. Biol. Control, 62: 144-151.

Zulperi, D., Sijama, K., Abidin, M.A.Z., Awang, Y. and Mohd, H.E. 2014. Phylotype classification of Ralstonia solanacearum biovar 1 strains isolated from banana (Musa spp.) in Malaysia. Archives of Phytopathol. Plant Protection, 47(19): 2352-2364.

\section{How to cite this article:}

Roop Singh and Jagtap, G.P. 2017. In Vitro Evaluation of Antibacterial Chemicals and Bioagents against Ralstonia solanacearum Infecting Bacterial Wilt in Ginger. Int.J.Curr.Microbiol.App.Sci. 6(5): 2034-2045. doi: https://doi.org/10.20546/ijcmas.2017.605.227 